\title{
Article
}

\section{Health inequalities between lone and couple mothers and policy under different welfare regimes - The example of Italy, Sweden and Britain}

Burstrom, Bo, Whitehead, Margaret, Clayton, Stephen, Fritzell, Sara, Vannoni, Francesca and Costa, Giuseppe

Available at http://clok.uclan.ac.uk/10738/

Burstrom, Bo, Whitehead, Margaret, Clayton, Stephen ORCID: 0000-00032823-1495, Fritzell, Sara, Vannoni, Francesca and Costa, Giuseppe (2010) Health inequalities between lone and couple mothers and policy under different welfare regimes - The example of Italy, Sweden and Britain. Social Science \& Medicine.

It is advisable to refer to the publisher's version if you intend to cite from the work.

For more information about UCLan's research in this area go to http://www.uclan.ac.uk/researchgroups/ and search for < name of research Group>.

For information about Research generally at UCLan please go to http://www.uclan.ac.uk/research/

All outputs in CLoK are protected by Intellectual Property Rights law, including Copyright law. Copyright, IPR and Moral Rights for the works on this site are retained by the individual authors and/or other copyright owners. Terms and conditions for use of this material are defined in the policies page. 


\title{
Health inequalities between lone and couple mothers and policy under different welfare regimes - The example of Italy, Sweden and Britain ${ }^{\text {is }}$
}

\author{
Bo Burstrom ${ }^{\mathrm{a}, *}$, Margaret Whitehead ${ }^{\mathrm{b}}$, Stephen Clayton $^{\mathrm{b}}$, Sara Fritzell ${ }^{\mathrm{a}}$, \\ Francesca Vannoni ${ }^{c}$, Giuseppe Costa ${ }^{c}$ \\ ${ }^{a}$ Karolinska Institutet, Stockholm, Sweden \\ ${ }^{\mathrm{b}}$ University of Liverpool, United Kingdom \\ ${ }^{\text {c } T u r i n ~ U n i v e r s i t y, ~ I t a l y ~}$
}

\section{A R T I C L E I N F O}

\section{Article history:}

Available online 8 January 2010

\section{Keywords:}

Health inequalities

Lone mothers

Welfare states

Italy

Britain

Sweden

Policy regimes

\begin{abstract}
A B S T R A C T
This study examines the welfare state arrangements and social policy, living conditions and health among lone and couple mothers in three contrasting policy environments: Italy, Sweden and Britain. These countries fall into distinctive family policy categories. Data were drawn from representative national household interview surveys. The findings highlight both similarities and differences. Lone mothers had significantly worse health than couple mothers in all three countries, were more likely to suffer material disadvantage and were much more likely to be smokers. They could be considered a disadvantaged group in particular need in all three countries, irrespective of the policy regime. It is the differences between countries, however, in the experiences of lone and couple mothers that indicate that the prevailing policy regime really does matter. There were telling differences in the prevalence of lone motherhood, their composition, rates of joblessness, poverty and health status of lone mothers in relation to couple mothers in each country. These may be traced back to the main policy regimes of each country, but also partly reflect culture and traditions. The study illustrates an emerging approach to investigating the health inequalities impact of complex social policy contexts. The experiences of lone mothers as a group may serve as a 'litmus' test of how each family policy system is operating and offer an early warning of adverse impacts when policies change.
\end{abstract}

(c) 2009 Elsevier Ltd. All rights reserved.

\section{Introduction}

Welfare state arrangements and social policies are important determinants of health and inequalities in health (Beckfield \& Krieger, 2009; Navarro et al., 2006; Wisdom, Berlin, \& Lapidus, 2005), though the challenge of assessing the full impact of wideranging policies is a monumental one. One promising approach to assessment is to focus more on specific groups in the population and on the particular policies or policy regimes that are likely to directly impinge on their lives, rather than a blanket approach. Lone mothers can be seen as one such group. In many societies, lone mothers are recognised as a potentially vulnerable group, whose

\footnotetext{
is This study was carried out within the EU Eurothine project. We are grateful to Eurothine colleagues for their considered comments on earlier drafts of this paper. No specific funding was received from the EU or any other source to carry out this study.

* Corresponding author. Karolinska Institutet, Department of Public Health Sciences, Division of Social Medicine, SE 171 76, Stockholm, Sweden.

E-mail address: bo.burstrom@ki.se (B. Burstrom).
}

living conditions are particularly sensitive to the setup of social policies, and who therefore may be among the first to be affected by any changes in welfare and employment policies. Our previous studies comparing Britain and Sweden showed substantial differences between the two countries in socio-economic circumstances of lone mothers over the decade from 1984 to 1995, relating to very different social welfare policies. We postulated that these differences led to very different pathways to the observed health disadvantage of lone mothers compared to couple mothers in the two countries (Whitehead, Burström, \& Diderichsen, 2000).

The study presented here examines the welfare state arrangements and social policy, living conditions and health among lone and couple mothers in three contrasting policy environments around the year 2000: Italy, Sweden and Britain. These countries were selected not only as representative of different types of welfare regime, but also because they fall into distinctive family policy categories of particular salience to parents with dependent children. The aim is to gain deeper understanding of how different policy regimes shape the lives, opportunities and ultimately health of parents in these countries. 
Model of family policy

As arrangements differ widely between countries, various welfare state typologies have been proposed, including most recently models that take account of the expansion of family policy and its effects on the lives of women(Ferrarini, 2006; Korpi, 2000). Fig. 1 illustrates the categorisation of family policy along two dimensions: the degree to which policy supports a traditional, nuclear family (where benefits, tax relief and leave entitlements support the father as the main breadwinner and the mother to stay at home to care for children) and the degree to which policy supports a dual-earner family. In this typology, Italy falls into the 'General family policy model', orientated towards preserving traditional family patterns through tax benefits for a working male with a dependent partner and flat-rate childcare leave benefits that encourage mothers to stay at home. Sweden falls into the 'Dualearner model', encouraging both fathers and mothers to work through family-friendly employment policies and universal preschool childcare provision. The UK falls into the 'Market-oriented model' with lower levels of support in both dimensions, leaving families to deal with family support and childcare privately through the market (Lundberg et al, 2008).

It is against this contrasting policy background that the experiences of lone versus couple mothers in the three countries are analysed in terms of social and health inequalities, using the following framework for studying the pathways from policy to health inequalities.

\section{Framework for studying pathways from policy to inequalities}

We use the framework developed by Diderichsen, Evans, and Whitehead (2001) to study the pathways from social context to health outcomes and the policy entry points along the way (Fig. 2). This framework takes the social context within which individuals are embedded to be a (dynamic) product of complex interactions of socioeconomic structures, economic, political and social policies, cultures and traditions. Thus, the social context can be viewed as the social and policy environment which shapes the life chances of individuals.

\section{Family policy models in different welfare systems}

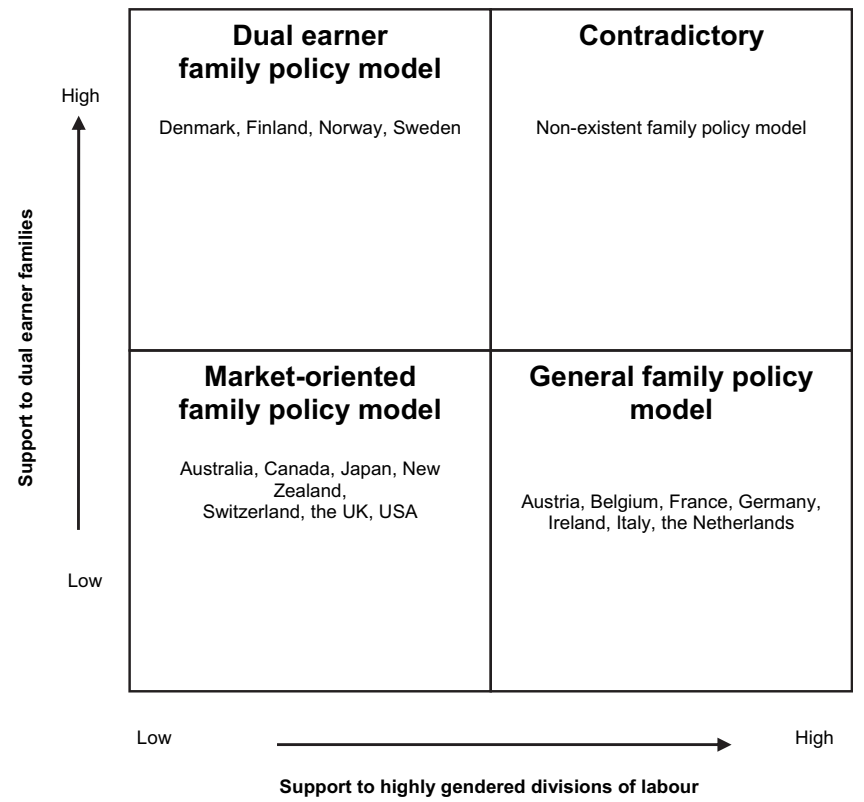

Fig. 1. Models of family policy in 18 countries around the year of 2000 . Adapted from Lundberg et al (2008).
The framework can be used to suggest possible pathways and mechanisms that lead to inequalities in health. The prevailing socio-economic structure affects the likelihood of an individual attaining a specific social position (Mechanism I, Social Stratification). For the individual, certain social positions are associated with an increased probability of exposures detrimental to health (Mechanism II, Differential Exposure). Lifestyles and health behaviours are not merely a choice of the individual but also a consequence of social position and environmental influences. Mechanism III, Differential Vulnerability, in Fig. 2 indicates that whether an exposure leads to ill health or not is in part dependent on the presence of other risk factors. For instance, unemployment may not be as detrimental to health for individuals with good social networks, who can receive economic, emotional and instrumental support. Lone mothers, however, are often exposed to several health risks, and these may further interact to produce higher susceptibility to ill health at a specified level of exposure. The framework in Fig. 2 also indicates that the social and economic consequences of disease or injury may differ between different groups (Mechanism IV, Differential Consequences), for instance between lone and couple mothers. Such a differential may also have a further impact on social stratification.

The social and policy context shapes the pathways from social position to ill health at several entry points (A, B, C, and D) depicted in Fig. 2, thereby potentially influencing population health in general and the pathways to inequalities in health in particular. Using Diderichsen's framework, this paper compares the policy context of lone and couple mothers in Italy, Sweden and Britain.

\section{Data and methods for the empirical analysis}

\section{Datasets}

We analysed representative national household interview surveys with cross-sectional data from Italy, Sweden and Britain.

For Sweden, data from three pooled years, 1999-2001, of the Swedish Survey of Living Conditions (ULF) conducted by Statistics Sweden were analysed (Statistics Sweden, 1994, 2006). The ULF is a continuous series of annual surveys, administered by face-to-face interviews, which draws a random sample of approximately 7500 people from all permanent residents in Sweden, aged between 16 and 84 years. The average response rate was above $75 \%$. The threeyear dataset contained 2302 couple mothers and 453 lone mothers aged between 16 and 59 .

For Britain, data from one year (mid 2000-mid 2001) of the General Household Survey (GHS) were analysed (Office for National Statistics, 2002). The GHS is a continuous, cross-sectional survey of private (non-institutional) households in Great Britain, administered by face-to-face interview to all adults aged 16 and over in the selected households. It achieved a sample size of 21,000 people of all ages, and a $72 \%$ response rate. We identified 2034 couple mothers and 652 lone mothers in the age range 16-59 for our analysis.

The Italian data were drawn from the National Health Survey for the period 1999-2000 (Italian Statistic Institute, 2003) by both face-to-face interview and self compiled questionnaires, on a sample representative of the non-institutionalised population, composed of 52,300 households, containing 140,011 individuals, randomly chosen within strata of geographical area, municipality and household size. The response rate was $86.6 \%$, comprising 21,133 couple mothers and 1911 lone mothers.

A mother was defined as a person who lives with at least one of her children aged under 18 years. A couple mother was defined as a mother who is either married or cohabiting and lives with her 

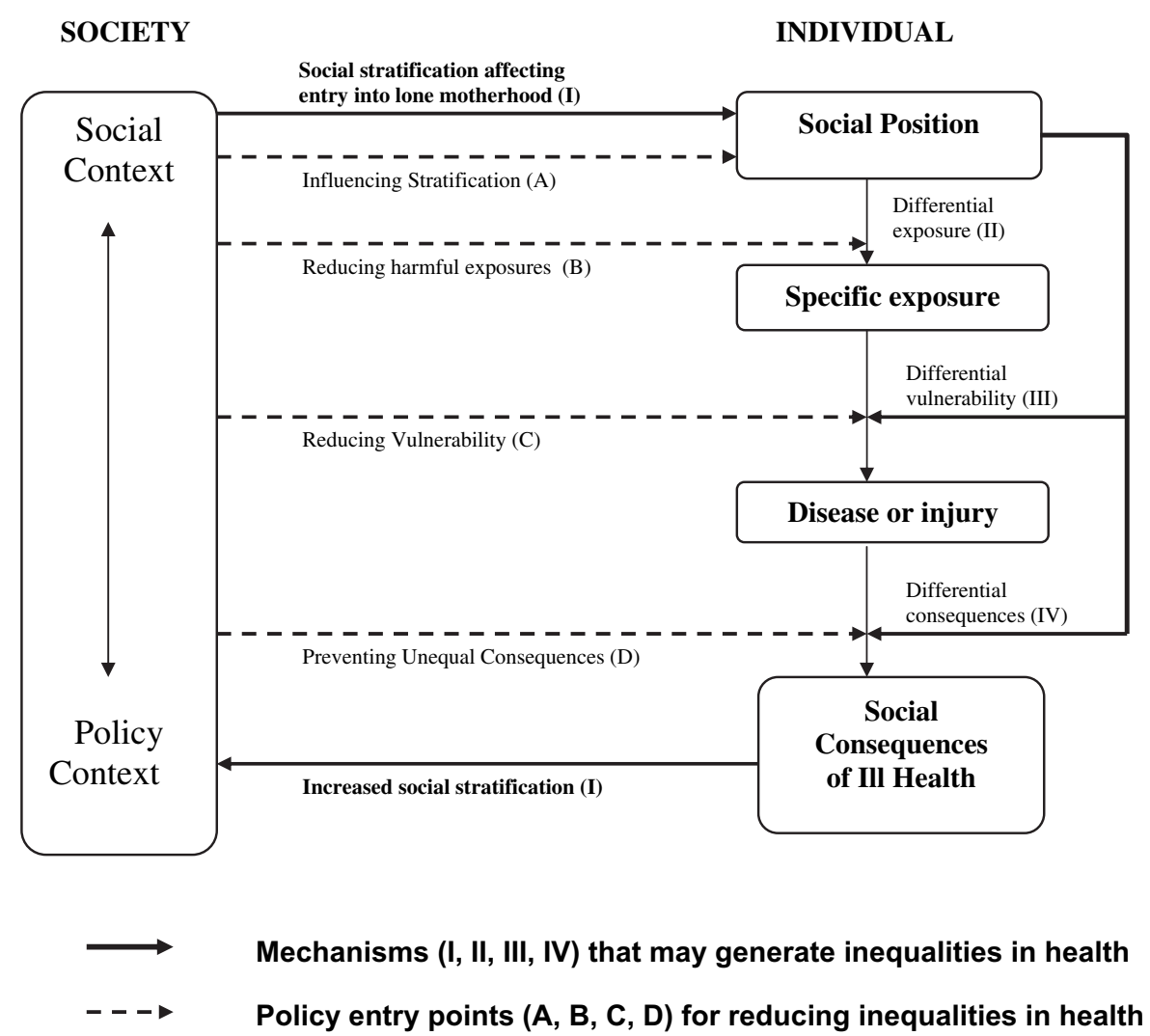

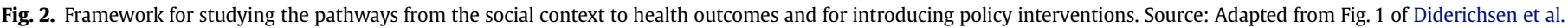
(2001).

partner. A lone mother may or may not be living with other adults in the household but does not live with a partner.

We employ an occupational definition of socio-economic position in which respondents were divided into three groups: "higher non-manual" which includes higher and intermediate non-manual groups; "lower non-manual"; and, a "manual group" which includes skilled and unskilled manual. A fourth group "never worked/inactive", includes those mothers who could not be classified into any of the other three groups.

For the poverty variable, no data were available for Italy. The Swedish survey defined low income as household income (excluding transfers) on a level below the social assistance threshold. In the British survey, low income was defined as less than $50 \%$ of the median income. Recent official statistics (Statistics Sweden, 2005), which use the less than $50 \%$ of median income measure, indicate that the poverty rate among lone mothers was $12 \%$ compared to $5 \%$ among couple mothers. The measure in the Swedish survey probably over-estimates the overall level of low income in Sweden.

Unemployment was defined according to the ILO definition (unemployment is a count of jobless people who want to work, are available to work, and are actively seeking employment).

Self-rated general health was used as a health outcome measure for the three countries, dichotomised into good and less than good health. Limiting longstanding illness (LLI) was used as a further health outcome measure in Sweden and Britain (not available for Italy). Direct age-standardised rates of less than good health and LLI were calculated using the World Health Organisation's European Standard population (Armitage \& Coulton, 1998). Confidence intervals around the European Standardised Rates (ESRs) were calculated according to Rothman and Greenland (1998).

\section{Findings and discussion of policy influences}

Do lone mothers have worse health than couple mothers in all three countries?

Lone mothers had worse self-rated general health than couple mothers in all three countries, for each of the age-groups and in the age-standardised rates. The prevalence of LLI (not available for Italy) was also higher among lone than couple mothers in both Britain and Sweden (Table 1). The gap in self-rated general health between lone and couple mothers was smaller in Italy than in Sweden and Britain, in both absolute and relative terms. The absolute differences in LLI between lone and couple mothers were larger in Sweden than in Britain, while relative differences were similar for this health measure (Table 1 ).

How might these inequalities in health be explained and what part do the different welfare systems play in the process? We explored three principal explanations: compositional factors and social position; differential exposure to risk factors and differential vulnerability.

\section{What differences in compositional factors and social position?}

Lone mothers may differ from couple mothers in their demographic and social characteristics, and the extent of variation may differ between countries, influenced, in part, by the process of social stratification and the social welfare context (Mechanism I and policy entry point A in Fig. 2). Women's economic independence depends on many factors, including welfare state, care and labour market policies (Huber, Stephens, Bradley, Moller, \& Nielsen, 2009). A range of policies may affect the age distribution or overall 
Table 1

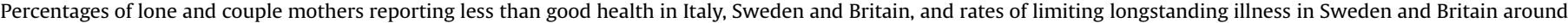
2000. Age standardised rates with $95 \%$ confidence intervals $(\mathrm{CI})$

\begin{tabular}{|c|c|c|c|c|c|c|}
\hline & \multicolumn{2}{|l|}{ Italy } & \multicolumn{2}{|l|}{ Sweden } & \multicolumn{2}{|l|}{ Britain } \\
\hline & $\begin{array}{l}\text { Lone } \\
(n=1911) \%\end{array}$ & $\begin{array}{l}\text { Couple } \\
(n=21133) \%\end{array}$ & $\begin{array}{l}\text { Lone } \\
(n=453) \%\end{array}$ & $\begin{array}{l}\text { Couple } \\
(n=2302) \%\end{array}$ & $\begin{array}{l}\text { Lone } \\
(n=652) \%\end{array}$ & $\begin{array}{l}\text { Couple } \\
(n=2034) \%\end{array}$ \\
\hline \multicolumn{7}{|l|}{ Less than good health } \\
\hline \multicolumn{6}{|l|}{ Age-specific rate } & $29.9(27.9-31.9)$ \\
\hline $16-24$ & $33.0(9.2-56.8)$ & $20.3(15.5-25.1)$ & $35.7(10.6-60.8)(5 / 14)^{\mathrm{a}}$ & $15.2(4.8-25.6)(7 / 46)^{a}$ & $32.2(24.8-39.6)$ & $28.0(22.8-33.2)$ \\
\hline $25-34$ & $31.5(25.2-37.8)$ & $27.1(25.8-28.4)$ & $28.3(20.2-36.4)$ & $14.1(11.5-16.7)$ & $44.8(38.1-51.5)$ & $30.3(26.6-34.0)$ \\
\hline $35-44$ & $36.7(32.7-40.7)$ & $35.3(34.3-36.3)$ & $29.2(22.9-35.5)$ & $16.3(14.1-18.5)$ & $42.9(36.3-49.5)$ & $28.3(25.3-31.3)$ \\
\hline $45-59$ & $58.3(55.4-61.2)$ & $54.4(53.3-55.5)$ & $38.5(29.7-47.3)$ & $20.8(17.2-24.4)$ & $57.8(46.4-69.2)$ & $35.2(29.7-40.7)$ \\
\hline $\begin{array}{l}\text { Age standardised rate } \\
\qquad(95 \% \mathrm{CI})\end{array}$ & $41.7(39.6-43.8)$ & $36.2(35.0-37.5)$ & $33.5(26.5-40.4)$ & $17.0(14.2-19.7)$ & $44.8(40.2-49.4)$ & $29.4(27.1-31.8)$ \\
\hline \multicolumn{7}{|c|}{ Limiting longstanding illness } \\
\hline $\begin{array}{l}\text { Crude prevalence rate } \\
\text { Age-specific rate }\end{array}$ & $n / a$ & $n / a$ & $26.7(22.6-30.8)$ & $16.4(14.9-17.9)$ & $16.9(14.0-19.8)$ & $11.3(9.9-12.7)$ \\
\hline $16-24$ & $n / a$ & $n / a$ & $21.4(-0.08-42.9)(3 / 14)^{\mathrm{a}}$ & $13.0(3.3-22.7)(6 / 46)^{\mathrm{a}}$ & $32.2(24.8-39.6)$ & $28.0(22.8-33.2)$ \\
\hline $25-34$ & $n / a$ & $n / a$ & $25.8(18.0-33.6)$ & $14.5(11.9-17.1)$ & $15.5(10.6-20.4)$ & $11.4(8.9-13.9)$ \\
\hline $35-44$ & $n / a$ & $n / a$ & $21.8(16.1-27.5)$ & $16.1(13.9-18.3)$ & $18.7(13.5-23.9)$ & $10.5(8.5-12.5)$ \\
\hline $45-59$ & $n / a$ & $n / a$ & $36.8(28.1-45.5)$ & $20.0(16.5-23.5)$ & $29.6(19.1-40.1)$ & $16.5(12.2-20.8)$ \\
\hline $\begin{array}{l}\text { Age standardised rate } \\
\qquad(95 \% \mathrm{CI})\end{array}$ & $n / a$ & $n / a$ & $27.4(21.3-33.6)$ & $16.3(13.7-18.9)$ & $19.5(15.6-23.4)$ & $12.0(10.3-13.7)$ \\
\hline
\end{tabular}

${ }^{\text {a }}$ Actual numbers indicated because of small $n$ aged 16-24 years in Swedish sample.

prevalence of lone motherhood in a country. Liberal divorce laws may increase the overall prevalence of lone motherhood, whilst the availability and quality of sex education and contraceptive services may help make the route into lone motherhood less common among young women. Abortion and adoption laws also affect the number of pregnancies brought to term and whether the children continue to live with a lone parent.

There were four striking differences between the countries in relation to the proportions and characteristics of lone mothers (Table 2). First, the likelihood of being a lone mother differed considerably between the countries, with Italy having the lowest prevalence ( $8.3 \%$ of all mothers), Sweden twice that prevalence (16.4\%) and Britain (24.3\%) almost three times greater prevalence of lone mothers than in Italy. Whilst the prevalence of lone motherhood in Italy had more than doubled from 3.2\% in the mid-1990s (Ruspini, 1998), rates in Sweden remained the same (16.0\% in the mid-1990s), while in Britain prevalence continued to increase (up from 20.9\% in the mid-1990s) (Whitehead et al., 2000). The Roman Catholic Church in Italy is opposed to divorce and separation, and other values such as family solidarity may also contribute to lower prevalence of lone motherhood in Italy (Flaquer, 2000). The increase in lone motherhood in recent decades in Italy may be a sign of emancipation of Italian women (Trifiletti et al, 2001).

The increase in lone motherhood in both Sweden and Britain has been attributed in part to the decline in stigma attached to divorce and unmarried motherhood (Land \& Lewis, 1998; Hobson \& Takahashi, 1997), accompanied by major relaxations in the divorce laws in the 1920s in Sweden and in the late 1960s in Britain. In contrast, divorce was not legalised in Italy until 1970 (Bimbi, 1997). In Sweden, a package of policies introduced already in the 1940s to improve the financial situation of families with children (in part in response to concerns about a falling birth rate), together with improvements in housing and access to services for all mothers, helped women with children gain autonomy. In Britain, a dramatic campaign to deal with homelessness in the mid-1970s led to a major change in housing legislation that enabled mothers who lived with other family members to set up their own households (Lewis, 1997).

Second, widowhood was a surprisingly common route into lone motherhood in Italy ( $36.2 \%$ of lone mothers are widows), whereas in Sweden and Britain it was rare, with only $1.3 \%$ and $2.8 \%$ respectively of lone mothers categorised as widows. In contrast, the most common routes into lone motherhood in Britain and Sweden were divorce ( $47.7 \%$ and $27.6 \%$ respectively) and being single/never married ( $44.1 \%$ and $50.8 \%$ respectively).

The relatively high rate of widowhood among Italian lone mothers is partially explained by demographic and cultural factors. Few Italian lone mothers re-partner (Istat 2007). Italy is experiencing a similar fall in the proportion of widows and increase in separated and divorced mothers with dependent children to that seen in other countries, but with a lag period of a decade or so. Many aspects of family formation in Italy, including lone motherhood, are being shifted to later phases of the life course by factors such as the falling birth rate and increasing age of mothers having their first child (Trifiletti et al, 2001). These factors, along with a tendency to avoid or postpone divorce in marriages with children and longer divorce proceedings, partly explain the older median age of Italian mothers, both lone and couple, compared to those in Sweden and Britain.

Third, the age distribution of lone mothers differed markedly. Italian lone mothers were older on average than their couple mother counterparts ( 47 years lone versus 42 years couple) and much older than lone mothers in Sweden (39 years lone, 38 years couple) and Britain (33 years lone, 36 years couple). The prevalence of young lone mothers was significantly higher in Britain, where $23.5 \%$ of lone mothers and $14 \%$ of couple mothers were aged $16-24$ years, compared to only $3.1 \%$ and $2 \%$ in Sweden and $0.8 \%$ and $1.3 \%$ in Italy, respectively. Although relatively few in number, young lone mothers in Italy are considered a vulnerable group (Saraceno, 2000).

The high proportion of young mothers, and especially young lone mothers, in Britain has been causing concern. Teenage mothers in particular are seen to have very disadvantaged trajectories throughout their lives and may lead to social exclusion (Social Exclusion Unit, 1999). Young girls and women from the lowest social class are ten times more likely to become teenage mothers than those from highest social class (Swann, Bowe, McCormick, \& Kosmin, 2003), and those in the poorest areas of England have teenage conception and birth rates up to six times higher than the most affluent areas (Social Exclusion Unit, 1999). 
Table 2

Characteristics of lone and couple mothers in Italy, Sweden and Britain around 2000.

\begin{tabular}{|c|c|c|c|c|c|c|}
\hline & \multicolumn{2}{|l|}{ Italy } & \multicolumn{2}{|l|}{ Sweden } & \multicolumn{2}{|l|}{ Britain } \\
\hline & Lone $(n=1911)$ & Couple $(n=21133)$ & Lone $(n=453)$ & Couple $(n=2302)$ & Lone $(n=652)$ & Couple $(n=2034)$ \\
\hline Lone mothers as \% of all mothers & $8.3(7.9-8.7)$ & & $16.4(15.2-17.8)$ & & $24.3(22.7-25.9)$ & \\
\hline $\begin{array}{l}\% \text { of lone mothers who are } \\
\text { widows }\end{array}$ & $36.2(34.0-38.4)$ & $0.2(0.1-0.3)$ & $1.3(0.3-2.3)$ & - & $2.8(1.5-4.1)$ & - \\
\hline Single/never married & $10.2(8.8-11.6)$ & $1.0(0.9-1.1)$ & $42.8(38.2-47.4)$ & - & $50.8(47.0-54.6)$ & - \\
\hline \% Divorced & $17.9(16.2-19.6)$ & $0.4(0.3-0.5)$ & $47.7(43.1-52.3)$ & - & $27.6(24.2-31.0)$ & - \\
\hline \% Separated & $35.8(33.7-37.9)$ & $0.4(0.3-0.5)$ & $8.2(5.7-10.7)$ & - & $18.9(15.9-21.9)$ & - \\
\hline \% Married & - & $98.1(97.9-98.2)$ & - & $68.1(66.2-70.0)$ & - & $76.4(74.6-78.2)$ \\
\hline$\%$ Cohabiting & - & $\mathrm{n} / \mathrm{a}$ & - & $30.7(28.8-32.6)$ & - & $23.6(21.8-25.4)$ \\
\hline Median age (years) & 47 & 42 & 39 & 38 & 33 & 36 \\
\hline$\%$ aged $16-24$ & $0.8(0.04-1.2)$ & $1.3(1.1-1.5)$ & $3.1(1.5-5.0)$ & $2.0(1.4-2.6)$ & $23.5(20.2-26.8)$ & $14.0(12.5-15.5)$ \\
\hline$\%$ aged $45-59$ & $59.1(56.9-61.3)$ & $39.9(39.2-40.6)$ & $21.7(17.9-25.5)$ & $25.8(24.0-27.6)$ & $11.0(8.6-13.4)$ & $14.3(12.8-15.8)$ \\
\hline \multicolumn{7}{|l|}{ Occupational class } \\
\hline$\%$ Higher non-manual & $6.9(5.8-8.0)$ & $5.5(5.2-5.8)$ & $28.7(24.5-32.9)$ & $40.1(38.1-42.1)$ & $7.4(5.4-9.4)$ & $12.5(11.1-13.9)$ \\
\hline \% Lower non-manual & $32.3(30.2-34.4)$ & $28.8(28.2-29.4)$ & $17.4(13.9-20.9)$ & $15.0(13.5-16.5)$ & $40.5(36.7-44.3)$ & $46.7(44.5-48.9)$ \\
\hline \% Manual & $24.6(22.7-26.5)$ & $17.2(16.7-17.7)$ & $40.2(35.7-44.7)$ & $38.0(36.0-40.0)$ & $36.0(32.3-39.7)$ & $28.7(26.7-30.7)$ \\
\hline $\begin{array}{l}\text { \% Never worked/inactive } \\
\text { (including students) }\end{array}$ & $36.3(34.1-38.5)$ & $48.5(47.8-49.2)$ & $13.7(10.5-16.9)$ & $6.9(5.9-7.9)$ & $16.1(13.3-18.9)$ & $12.1(10.7-13.5)$ \\
\hline
\end{tabular}

The high proportion of teenage mothers has been recognised and been the focus of a number of policy initiatives in the UK, though some of the approaches are contested (Graham \& McDermott, 2005).

Fourth, there are occupational class differences (Table 2). In Italy, one-third to one-half of mothers were in the never worked/inactive category ( $36.3 \%$ lone versus $48.5 \%$ couple mothers). There were relatively few mothers, whether lone or couple, in the higher nonmanual classes (6.9\% and 5.5\% respectively). Sweden and Britain had the smaller proportions of mothers (lone and couple) in the never worked/inactive category. In Sweden lone mothers were more evenly distributed among the classes, with $28.7 \%$ in the higher non-manual group. However, $40.1 \%$ of Swedish couple mothers were in the higher non-manual category. Britain demonstrated a third pattern, with most mothers, whether lone or couple, concentrated in the lower-non-manual and manual classes, and relatively few in either the higher non-manual or inactive categories. Like in Sweden, however, the overall occupational class distribution of British lone mothers was less favourable than for couple mothers: lower proportions of lone mothers in the two nonmanual classes and greater proportions in the manual class, compared with their couple mother counterparts.

Taken as a whole, these findings point to different pathways into lone motherhood in the three countries, and to different social positions for lone compared to couple mothers, which again varied across the countries.

Do differences between lone and couple mothers in the social positions they occupy account for the observed differences in health status shown in Table 1 . This question was explored further in Table 3. There was a clear social gradient in the proportion with less than good health, with increasing prevalence moving from higher non-manual to manual classes, for lone mothers in all three countries. There was also an occupational class gradient for couple mothers in Italy and Britain, but not quite as linear in Sweden. This indicates that the more disadvantaged social position of lone compared with couple mothers may be playing a role in the observed inequalities in health between lone and couple mothers to a varying degree in the three countries.

The horizontal relationships, however, reveal a more complex picture. In all but one case, prevalence rates of less than good health were higher for lone than couple mothers within each occupational class, indicating that there was a health disadvantage of being a lone mother over and above that associated with their particular occupation class, in all three countries, though the differences between lone and couple mothers were very small in Italy. The exception relates to Italian lone mothers in the higher non-manual occupational class, where lone mothers had lower rates of less than good health than couple mothers (though not statistically significant) (Table 3, columns 1 and 2). This may indicate that for the (relatively few) mothers in Italy in the most advantaged social position, their privileged circumstances may overcome the health disadvantage associated with being a lone mother. Repeating the analysis in relation to LLI revealed a similar marked social gradient in illness and similar relationships between lone and couple mothers in each occupational class in both Sweden and Britain, again with the exception of Swedish higher non-manual couple mothers, who had higher rates of LLI than their lower non-manual counterparts (data for Italy not available).

\section{What differences in exposure to health risks?}

Theoretically, a second mechanism bringing about the observed inequalities in health between lone and couple mothers may be differential exposure to health risks (Mechanism II and entry point B in Fig. 2). By virtue of being sole providers, for example, lone mothers may run the risk of poverty. Various social and labour market policies may aim at decreasing this risk either directly through social assistance benefits, universal child allowances, and child maintenance advances for lone parents, or indirectly by providing subsidised child care and thereby facilitating employment. Flexible employment options for parents, such as the 'parentworker' model in Sweden (Lewis \& Hobson, 1997), which includes a generous, paid parental leave and subsidised institutions for childcare, provides parents (both couple and lone) with more flexibility to negotiate the work/family balance. Other policies in terms of labour market legislation and social insurance systems may affect lone mothers differently from couple mothers.

When women become lone mothers, therefore, an important question is the extent to which the social welfare system protects them from exposure to such health risks, and whether different types of system are more or less effective in this respect. Table 4 shows that lone mothers were worse off financially in all three countries. A proxy measure of low income - the proportion living in rented accommodation, rather than owning their own home - was much higher among lone mothers in all three countries (Table 4). A higher proportion of lone than couple mothers were poor in both 
Table 3

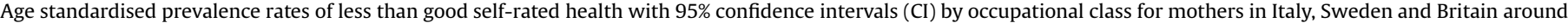
2000, and age-standardised rates of limiting longstanding illness in Sweden and Britain.

\begin{tabular}{|c|c|c|c|c|c|c|}
\hline \multirow[t]{2}{*}{ Age standardised prevalence rate (\%), $95 \% \mathrm{CI}$} & \multicolumn{2}{|l|}{ Italy } & \multicolumn{2}{|l|}{ Sweden } & \multicolumn{2}{|l|}{ Britain } \\
\hline & Lone $(n=1911)$ & Couple $(n=21133)$ & Lone $(n=453)$ & Couple $(n=2302)$ & Lone $(n=652)$ & Couple $(n=2034)$ \\
\hline \multicolumn{7}{|l|}{$\begin{array}{l}\text { Less than good health } \\
\text { Occupational class }\end{array}$} \\
\hline Higher non-manual & $21.0(15.5-26.4)$ & $28.1(25.2-31.0)$ & $19.1(13.6-24.5)$ & $14.5(5.5-23.6)$ & $38.7(18.7-58.7)$ & $19.3(14.5-24.0)$ \\
\hline Lower non-manual & $38.3(35.7-41.0)$ & $34.7(33.5-36.0)$ & $28.7(20.1-37.2)$ & $11.3(8.0-14.7)$ & $42.8(35.4-50.2)$ & $29.9(25.9-33.9)$ \\
\hline Manual & $46.4(40.3-52.5)$ & $42.6(41.5-43.7)$ & $40.6(31.1-50.1)$ & $21.6(17.5-25.6)$ & $55.0(47.7-62.2)$ & $34.6(29.8-39.4)$ \\
\hline Never worked/inactive (including students) & $44.2(40.4-48.1)$ & $38.2(37.4-39.1)$ & $33.1(18.2-48.0)$ & $20.0(9.6-30.5)$ & $35.4(15.8-55.1)$ & $34.6(21.5-47.7)$ \\
\hline \multicolumn{7}{|l|}{$\begin{array}{l}\text { Limiting longstanding illness } \\
\text { Occupational class }\end{array}$} \\
\hline Higher non-manual & $\mathrm{n} / \mathrm{a}$ & $\mathrm{n} / \mathrm{a}$ & $21.0(15.4-26.5)$ & $14.8(5.7-23.8)$ & $11.4(1.5-21.3)$ & $9.2(5.6-12.9)$ \\
\hline Lower non-manual & $\mathrm{n} / \mathrm{a}$ & $\mathrm{n} / \mathrm{a}$ & $19.2(12.0-26.3)$ & $11.1(7.8-14.4)$ & $15.6(10.3-21.0)$ & $10.5(7.9-13.1)$ \\
\hline Manual & $\mathrm{n} / \mathrm{a}$ & $\mathrm{n} / \mathrm{a}$ & $33.3(23.9-42.7)$ & $20.5(16.4-24.5)$ & $25.3(18.0-32.6)$ & $15.1(11.5-18.6)$ \\
\hline Never worked/inactive (including students) & $\mathrm{n} / \mathrm{a}$ & $\mathrm{n} / \mathrm{a}$ & $32.4(18.7-46.0)$ & $23.9(13.0-34.8)$ & $31.6(14.6-48.6)$ & $13.3(2.5-24.1)$ \\
\hline
\end{tabular}

Britain and Sweden, although much higher in Britain, with $50 \%$ of lone mothers classed as poor, compared to $19 \%$ among couple mothers. In Sweden, the corresponding poverty rates were $16 \%$ and nearly $10 \%$ respectively. Caution is needed, however, in comparing the absolute rates of poverty in Table 4 because the poverty variables from the British and Swedish surveys have different definitions. Italian data for poverty were not available. However, in the mid-1990s, lone mother poverty rates were $25 \%$ among those who worked and $79 \%$ among those who did not, reflecting that social transfers were limited (Esping-Andersen, 2002).

Italian lone mothers were more likely than their couple-mother counterparts to be employed (nearly $58 \%$ compared to $44 \%$ of couple mothers) and less likely to be unemployed (Table 4). The Italian pattern contrasted with both Britain and Sweden, where lone mothers had lower chances of employment and higher rates of unemployment than couple mothers.

However, comparing the countries, the overall level of employment among mothers was highest in Sweden, where 77\% of lone mothers and $84 \%$ of couple mothers were employed. In Britain, half of lone mothers and $69 \%$ of couple mothers were employed. Italy had the lowest level of employment: $58 \%$ for lone and $44 \%$ for couple mothers. The high level of participation on the labour market in Sweden in part reflects the greater availability and use of day care compared to Britain and Italy. Following a number of policy initiatives in Britain since the late 1990s, including greater availability of child care, tax credits for child care and for workers on low income, and other welfare reforms, employment rates among lone mothers have increased substantially, resulting in declining rates of poverty among lone mothers and among children in general (Department of Health, 2005). Maternity leave policies have improved both in Britain and in Sweden, although British maternity leave remains at half the level of Sweden.
A significant proportion of Italian lone mothers were living with another adult in the household. This was generally another family member who could also provide childcare (Gardberg Morner, 2000), which might explain the higher employment rate among Italian lone mothers compared to couple mothers, combined with the pressure on lone mothers to earn their own income (EspingAndersen, 2002). Child care in Italy is scarce and expensive for children under three, but for 3-6 year-olds child care is provided universally at only the costs of meals, resulting in $90 \%$ of children being enrolled. Lone mothers in Italy work longer hours compared to partnered ones (the weekly average hours are, respectively, 44 and 41). These differences are also linked to the higher rate of parttime work among couple mothers (29.3\% compared to $21.8 \%$ of lone mothers) because lone mothers cannot afford the drop in income associated with part-time jobs (Sabbadini, 2006).

Smoking is another risk factor for poor health. In all countries, lone mothers had a higher prevalence of smoking than couple mothers. Britain had the highest prevalence of smoking for both groups, with almost half of all lone mothers smoking daily, compared to only a quarter of couple mothers. In Sweden, whilst overall prevalence was lower, more than twice as many lone mothers smoked daily than couple mothers. In Italy, the prevalence of smoking was slightly lower than in Sweden (Table 4). This differential exposure to smoking may partly reflect a coping behaviour among lone mothers, in response to stress (Graham, 1993).

The extent to which the differing welfare systems protected mothers from poverty and non-employment in 2000/2001 is explored in Table 5 for Sweden and Britain (data for Italy not available). Being employed greatly reduced the risk of poverty in both countries and for both lone and couple mothers, most strikingly so for lone mothers in Britain, where the poverty rate was $50 \%$

Table 4

Exposure to poverty, joblessness and smoking among lone and couple mothers in Italy, Sweden, and Britain around 2000.

\begin{tabular}{|c|c|c|c|c|c|c|}
\hline \multirow[t]{2}{*}{ Prevalence rate (\%) } & \multicolumn{2}{|l|}{ Italy } & \multicolumn{2}{|l|}{ Sweden } & \multicolumn{2}{|l|}{ Britain } \\
\hline & Lone $(n=1911)$ & Couple $(n=21133)$ & Lone $(n=453)$ & Couple $(n=2302)$ & Lone $(n=652)$ & Couple $(n=2034)$ \\
\hline Employed & $57.8(55.6-60.0)$ & $44.3(43.6-45.0)$ & $77.0(73.1-80.9)$ & $84.0(82.5-85.5)$ & $50.4(46.6-54.2)$ & $69.4(67.4-71.4)$ \\
\hline Unemployed (ILO definition) & $7.2(6.0-8.4)$ & $8.5(8.1-8.9)$ & $10.8(7.9-13.7)$ & $7.3(6.2-8.4)$ & $7.9(5.8-10.0)$ & $2.1(1.5-2.7)$ \\
\hline Not seeking work/keeping house & $35.0(32.9-37.1)$ & $47.2(46.5-47.9)$ & $13.9(10.7-17.1)$ & $11.3(10.0-12.6)$ & $41.6(37.8-45.4)$ & $28.1(26.1-30.1)$ \\
\hline Renting accommodation & $34.2(32.1-36.3)$ & $19.1(18.6-19.6)$ & $65.1(60.7-69.5)$ & $21.6(19.9-23.3)$ & $65.2(61.5-68.9)$ & $21.0(19.2-22.8)$ \\
\hline Poor $^{\mathrm{a}}$ & $\mathrm{n} / \mathrm{a}$ & $\mathrm{n} / \mathrm{a}$ & $16.1(12.7-19.5)$ & $9.9(8.7-11.1)$ & $50.3(46.5-54.1)$ & $19.1(17.4-20.8)$ \\
\hline Poor among employed & $\mathrm{n} / \mathrm{a}$ & $\mathrm{n} / \mathrm{a}$ & $9.9(6.8-13.0)$ & $7.4(6.2-8.6)$ & $19.3(15.3-23.6)$ & $11.8(10.1-13.5)$ \\
\hline Poor among not employed & $\mathrm{n} / \mathrm{a}$ & $\mathrm{n} / \mathrm{a}$ & $36.3(28.6-44.0)$ & $23.2(18.9-27.5)$ & $80.1(75.7-84.4)$ & $35.8(32.0-39.6)$ \\
\hline Smoking daily & $31.6(29.5-33.7)$ & $21.2(20.6-21.8)$ & $37.4(32.9-41.9)$ & $18.1(16.5-19.7)$ & $48.0(44.2-51.8)$ & 24.8 (22.9-26.7) \\
\hline
\end{tabular}

a Sweden: household income (excluding transfers) on level below social assistance threshold. Britain: $<50 \%$ of median income. 
Table 5

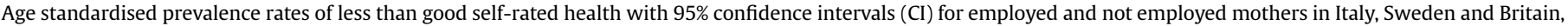
and age-standardised prevalence rates of limiting longstanding illness in Sweden and Britain around 2000.

\begin{tabular}{|c|c|c|c|c|c|c|}
\hline \multirow[t]{2}{*}{ Age standardised prevalence rate (\%), 95\% CI } & \multicolumn{2}{|l|}{ Italy } & \multicolumn{2}{|l|}{ Sweden } & \multicolumn{2}{|l|}{ Britain } \\
\hline & Lone $(n=l 911)$ & Couple $(n=21133)$ & Lone $(n=453)$ & Couple $(n=2302)$ & Lone $(n=652)$ & Couple $(n=2034)$ \\
\hline \multicolumn{7}{|l|}{ Less than good health } \\
\hline Not employed & $42.6(39.9-45.4)$ & $37.6(35.9-39.3)$ & $50.2(38.0-62.3)$ & $31.8(25.7-37.9)$ & $54.1(47.1-61.1)$ & $38.7(33.9-43.5)$ \\
\hline Employed & $42.2(39.4-44.9)$ & $34.2(33.4-35.1)$ & $24.9(17.4-32.5)$ & $14.0(10.1-17.8)$ & $36.8(30.7-42.8)$ & $26.6(23.9-29.4)$ \\
\hline Rate difference & 0.4 & 3.4 & 25.3 & 17.8 & 17.3 & 12.1 \\
\hline \multicolumn{7}{|l|}{ Limiting longstanding illness } \\
\hline Not employed & $\mathrm{n} / \mathrm{a}$ & $\mathrm{n} / \mathrm{a}$ & $46.6(35.1-58.0)$ & $30.6(24.9-36.4)$ & $32.2(25.1-39.2)$ & $23.1(18.6-27.5)$ \\
\hline Employed & $\mathrm{n} / \mathrm{a}$ & $\mathrm{n} / \mathrm{a}$ & $21.4(14.0-28.8)$ & $15.2(10.8-19.6)$ & $9.9(5.8-14.0)$ & $8.4(6.7-10.1)$ \\
\hline Rate difference & $\mathrm{n} / \mathrm{a}$ & $\mathrm{n} / \mathrm{a}$ & 25.2 & 15.4 & 22.3 & 14.2 \\
\hline
\end{tabular}

among non-employed lone mothers and 19\% among working lone mothers. This also illustrates the severe problem of poverty for lone mothers who do not work, and the deficiencies in the British social welfare system, which fails to protect a high proportion of them. The Swedish welfare system fares better in this respect. The poverty rate of $36 \%$ among lone and $23 \%$ among couple mothers who do not work, however, is an indication that the Swedish system is falling short of full protection. The economic situation of Swedish lone mothers has deteriorated in recent years. A greater proportion were not employed and had financial difficulties in the 1990s than in the 1980s (Burström, Diderichsen, Shouls, \& Whitehead, 1999; Fritzell \& Burström, 2006). Comparable Italian data were lacking, but previous studies have suggested that the rate of poverty is similar among lone and couple mothers (about 13\%), and increases with the number of children (Brandolini \& Saraceno, 2007). Poverty among lone mothers in Italy is also linked to nonemployment, as social transfers are low and reduce poverty only by $13.9 \%$ compared with $49.9 \%$ in Sweden and $36.4 \%$ in the UK (EspingAndersen, 2002).

\section{What differences in vulnerability?}

A further potential pathway to health inequalities between lone and couple mothers is greater vulnerability to the health damage caused by risk factors such as joblessness and poverty (Mechanism III and entry point $C$ in Fig. 2). This was explored in Table 6. Because some of the sub-groups are based on small numbers, interpretation can only be tentative. In Italy, there were little or no differences in rates of less than good health between employed and not employed for lone and couple mothers, and the rate difference was actually bigger for the couple mothers (Table 6). There was therefore no indication of greater vulnerability of lone mothers in Italy to the health effects of joblessness; if anything, it was the couple mothers who were more vulnerable. This may partly be due to selection, as divorce and separation is more common among highly educated women (Esping-Andersen, 2002). In Sweden and Britain, the differences in rates of less than good health between employed and not employed lone mothers were substantially higher than among couple mothers, indicating that lone mothers in both Sweden and Britain may be more vulnerable than couple mothers to the health damage of joblessness. A similar pattern was found for LLI (data on LLI for Italy not available). Of further note are the very high rates of ill health among lone and couple Swedish mothers who were not working, higher than our Anglo-Swedish comparisons of the 1990s (Whitehead et al., 2000), which may suggest that health selection into and out of the labour market has become more pronounced than before in Sweden, and may be related to a harsher labour market and employment policy climate.

In relation to poverty, there was no indication of greater vulnerability of lone mothers in either Sweden or Britain from the rate differences presented in Table 6 . The rate differences were only marginally larger for lone compared with couple mothers, and indeed when self-rated general health was used as a measure, couple mothers had a larger rate difference than lone mothers There was a tentative indication, however, that poverty may be more damaging to health in Britain than in Sweden when health is measured by LLI: there was no difference in the prevalence of LLI among poor compared to not-poor Swedish mothers (rate differences of -1.8 for lone and -1.3 for couple mothers), while in Britain prevalence of LLI was higher among poor compared to non-poor mothers (rate difference of 7.6 for lone and 5.3 for couple).

\section{Strengths and limitations of the study}

In terms of limitations, some of the variables in the surveys are not entirely comparable for cross-country comparative purposes. Slight differences in the wording and definition of the health variables, for example, mean that the absolute values for prevalence of ill health cannot be compared across countries. However, comparisons of relative differences in prevalence of ill health

Table 6

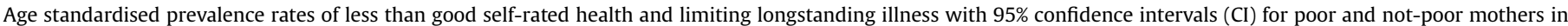
Sweden and Britain around 2000.

\begin{tabular}{|c|c|c|c|c|}
\hline \multirow[t]{2}{*}{ Prevalence rate (\%) 95\% CI } & \multicolumn{2}{|l|}{ Sweden } & \multicolumn{2}{|l|}{ Britain } \\
\hline & Lone $(n=453)$ & Couple $(n=2302)$ & Lone $(n=652)$ & Couple $(n=2034)$ \\
\hline \multicolumn{5}{|l|}{ Less than good health } \\
\hline Poor & $40.0(25.9-54.1)$ & $20.3(12.3-28.3)$ & $48.1(40.8-55.5)$ & $35.1(29.0-41.2)$ \\
\hline Not poor & $35.0(26.2-43.7)$ & $16.5(13.5-19.5)$ & $42.9(36.4-49.3)$ & $27.8(25.0-30.6)$ \\
\hline Rate difference & 5.0 & 3.9 & 5.3 & 7.3 \\
\hline \multicolumn{5}{|c|}{ Limiting longstanding illness } \\
\hline Poor & $28.0(16.2-39.8)$ & $14.9(7.8-22.1)$ & $23.9(17.1-30.8)$ & $16.5(11.6-21.5)$ \\
\hline Not poor & $29.8(21.4-38.1)$ & $16.1(13.3-18.9)$ & $16.3(11.3-21.4)$ & $11.2(9.2-13.2)$ \\
\hline Rate difference & -1.8 & -1.3 & 7.6 & 5.3 \\
\hline
\end{tabular}


between lone and couple mothers are still valid. It is also still valid to make comparisons of the absolute and relative inequalities in health and social circumstances between different sub-groups within each country, as the same survey questions were administered to each sub-group. Some variables, for example income and limiting longstanding illness, were not available for Italy. The smaller sample size in Sweden and Britain and resulting lack of power in some sub-groups restricted the extent of the sub-group analyses and statistical testing for these countries. The sub-groups based on small numbers are indicated in the tables and the results should be seen as indicative only. Nevertheless, there are considerable strengths to this study, including the way it integrates the empirical data with policy analysis, which in turn aids the identification of potential policy entry points for tackling inequalities in health. Finally, the comparison between different types of welfare regime is made more powerful by moving away from general welfare policy to the specific: by focusing the enquiry on family policy models, most relevant to the lives of lone and couple mothers, and by disaggregating the individual-level data to analyse how mothers in different circumstances fare in their day-to-day lives under the influence of these policies.

\section{Conclusions}

The study highlights some similarities, but also many differences between the experiences and circumstances of lone compared with couple mothers in the three countries, which reflect the contrasting policy regimes.

In terms of similarities, lone mothers had significantly worse health than couple mothers in all three countries. In addition, lone mothers were more likely to suffer material disadvantage in all three countries and were much more likely to be smokers. They could be considered a disadvantaged group in particular need in all three countries, irrespective of the policy regime.

It is the differences between countries, however, in the experiences of lone and couple mothers that indicate that the prevailing policy regime really does matter. Some of the differences identified in this study (such as in relation to the prevalence of lone motherhood, and their class composition, rates of joblessness, poverty and health status compared with couple mothers), may be traced back to the main policy regimes in the welfare system of each country, but also partly reflects culture and traditions.

The dual-earner family policy model, coupled with the generosity of family benefits, has clearly protected Swedish mothers in general and lone mothers in particular from the degree of poverty experienced among British lone mothers and helps them achieve much higher rates of employment than in both Italy and Britain. The higher employment rate, and greater proportions in higher occupational classes observed among Swedish women overall is largely a result of longstanding general welfare state policies, promoting gender and social equality. Furthermore, family-friendly employment policies and access to universal childcare services may be more important to lone than couple mothers, as they are sole carers. Such a universal service may be an example of a general intervention with a greater impact for lone than couple mothers, i.e. with the potential to reduce inequalities between the two groups.

The findings from Britain are in line with the market-oriented family policy model that has been dominant there for many decades. The lower rates of employment among British mothers in general and lone mothers in particular, and a high prevalence of poverty among lone mothers (50\% rising to $80 \%$ for lone mothers who are not working), reflect the relatively low level of social security support for parents who are not working, lack of (until recently) family-friendly employment policies and affordable day care for children. This last factor - lack of affordable childcare - is considered to be one of the most important barriers to employment for British mothers in general, but an even greater barrier for lone mothers living on low income and without other family support (Jenkins \& Symons, 2001; Viitanen, 2005).

The Italian findings contrast with those of Sweden and Britain in several key ways, and illustrate the impact of the prevailing general family policy model. A sizeable proportion of Italian mothers, both lone and couple, were classed as not working or keeping house, which reflects both the longstanding policy objectives of encouraging mothers to stay at home and the religious and cultural traditions. Among mothers who were working, however, a striking contrast with Sweden and Britain was that lone mothers had higher employment rates than couple mothers, despite the lack of universal childcare provision for children under three. A likely explanation is the provision of childcare by family members combined with the pressure on lone mothers to earn their own income (Esping-Andersen, 2002).

The findings illustrate the value of doing sub-group analyses to look at how mothers fare under different conditions in the same country. It is also important to take into consideration change - in the population and in policy. Lone motherhood is a dynamic phenomenon, as indicated by the increasing prevalence rates in Italy and Britain and reflected to some extent in the demographic and socio-economic composition of lone mothers in the different countries. There may be very different reasons for becoming a lone mother, and the social and economic circumstances and trajectories of lone mothers vary correspondingly.

The living conditions of lone mothers may also change over time, as policies change. Concerted policy initiatives by the British government over the last decade have been partially successful in increasing rates of employment and lowering poverty rates among lone mothers. Conversely, in Sweden rates of non-employment and financial difficulties among lone mothers increased during the 1990s, due in part to cuts in universal services and policy shifts in response to a worsening economic climate. Nevertheless, lone and couple mothers in Sweden still have higher employment rates than lone and couple mothers in Italy and Britain. In Italy there have been no direct policy changes aimed at improving the living conditions and health of lone mothers. Given the increase in the prevalence of lone motherhood in Italy, now seems to be the time to consider such policies, keeping in mind that the heterogeneity of the group would necessitate different policies to meet different needs.

Finally, the study illustrates an emerging approach to investigating the health and health inequalities impact of complex social policy contexts, using Diderichsen's framework for studying pathways to health inequalities and policy entry points. We suggest that the experiences of lone mothers as a group may serve as a 'litmus' test of how each family policy system is operating and offer an early warning of adverse impacts when policies change.

\section{References}

Armitage, P., \& Coulton, T. (Eds.). (1998). Encyclopedia of biostatistics. Chichester: Wiley.

Beckfield, J., \& Krieger, N. (2009). Epi + demos + cracy: linking political systems and priorities to the magnitude of health inequities - evidence, gaps and a research agenda. Epidemiological Reviews, 31, 152-177.

Bimbi, F. (1997). Lone mothers in Italy: a hidden and embarrassing issue in a familist welfare regime. In J. Lewis (Ed.), Lone mothers in European welfare regimes: Shifting policy logics (pp. 171-202). London: Jessica Kingsley.

Brandolini, A., \& Saraceno, C. (2007). Povertà e benessere. Una geografia delle disuguaglianze in Italia. Bologna: Il Mulino.

Burström, B., Diderichsen, F., Shouls, S., \& Whitehead, M. (1999). Lone mothers in Sweden: trends in health and socio-economic circumstances, 1979-1995. Journal of Epidemiology Community Health, 53, 750-756.

Department of Health (DoH). (2005). Tackling health inequalities: Status report on the programme for action. London: $\mathrm{DoH}$. 
Diderichsen, F., Evans, T., \& Whitehead, M. (2001). The social basis of disparities in health. In T. Evans, M. Whitehead, F. Diderichsen, A. Bhuiya, \& M. Wirth (Eds.) Challenging inequities in health. From ethics to action (pp. 12-23). New York: Oxford University Press.

Esping-Andersen, G. (2002). Why we need a new welfare state. Oxford: Oxford University Press.

Ferrarini, T. (2006). Families, states and labour markets: Institutions, causes and consequences of family policy in post-war welfare states. Cheltenham: Edward Elgar Publishing.

Flaquer, L. (2000). Family policy and welfare state in Southern Europe. Barcelona: Institut De Cièncices Politiques I Socials.

Fritzell, S., \& Burström, B. (2006). Economic strain and self-rated health among lone and couple mothers in Sweden during the 1990s compared to the 1980s. Health Policy, 79, 253-264.

Gardberg Morner, C. (2000). Making ends meet. Lone mothers' subsistence strategies. Case studies from Italy and Sweden. Mannheim: Mannheimer Zentrum Fur Europäische Sozialforschung (MZES). Arbeitspapiere/Working Paper No 13.

Graham, H. (1993). When life's a drag: Women, smoking and disadvantage. London: HMSO.

Graham, H., \& McDermott, E. (2005). Qualitative research and the evidence base of policy: insights form studies of teenage mothers in the UK. Journal of Social Policy, 35(1), 21-37.

Hobson, B., \& Takahashi, M. (1997). The parent-worker model: lone mothers in Sweden. In J. Lewis (Ed.), Lone mothers in European welfare regimes: Shifting policy logics. London: Jessica Kingsley.

Huber, E., Stephens, J. D., Bradley, D., Moller, S., \& Nielsen, F. (2009). ) The politics of women's independence. Social Politics, 16, 1-39.

Italian Statistic Institute. (2003). La cura e il ricorso ai servizi sanitari. Indagine Multiscopo sulle famiglie "Condizioni di salute e ricorso ai servizi sanitari" Anni 1999-2000. 2003, Informazioni, n. 7 (In Italian). Roma: ISTAT. Available from:. http://www.istat.it/dati/catalogo/20020724_00/Volume_IV.pdf.

Jenkins, S. P., \& Symons, E. J. (2001). Child care costs and lone mothers' employment rates: UK evidence. The Manchester School, 69(2), 121-147.

Korpi, W. (2000). Faces of inequality: gender, class, and patterns of inequalities in different types of welfare states. Social Politics, 7(2), 127-191.

Land, H., \& Lewis, J. (1998). The problem of lone motherhood in the British context. In R. Ford, \& J. Millar (Eds.), Private lives and public responses: Lone parenthood and future policy in the UK. London: PSI.

Lewis, J. (1997). Lone mothers: the British case. In J. Lewis (Ed.), Lone mothers in European welfare regimes: Shifting policy logics. London: Jessica Kingsley.

Lewis, J., \& Hobson, B. (1997). Introduction. In J. Lewis (Ed.), Lone mothers in European welfare regimes: Shifting policy logics (pp. 1-20). London: Jessica Kingsley.
Health Equity Studies no. 12. Centre for Health Equity Studies (CHESS). In Lundberg, O., Aberg Yngwe, M., Kolegard Stjarne, M., Bjork, L., \& Fritzell, J. (Eds.) The Nordic experience: Welfare states and public health (NEWS). Stockholm: Stockholm University/Karolinska Institute.

Navarro, V., Muntaner, C., Borrell, C., Benach, J., Quiroga, A., Rodriguez-Sanz, M., et al. (2006). Politics and health outcomes. Lancet, 368, 1033-1037.

Office for National Statistics. (2002). General household survey: Living in Britain 2001. London: The Stationery Office.

Rothman, K., \& Greenland, S. (1998). Modern epidemiology (2nd ed.). Philadelphia: Lippincott Raven.

Ruspini, E. (1998). Living on the poverty line. Lone mothers in Belgium, Great Britain Italy and Sweden. Mannheim: Mannheimer Zentrum fur Europäische Sozialforschung (MZES). Arbeitsbereich Working Paper I/No. 28

Sabbadini, L. L. (2006). Madri sole. Profili e tempi di vita in Italia. In F. Bimbi, \& R. Trifiletti (Eds.), Madri sole e nuove famiglie. Declinazioni inattese della genitorialità (pp. 37-54). Roma: Edizioni Lavoro.

Saraceno, C. (2000). Gendered policies, family obligations and social policies in Europe. In T. P. Boje, \& A. Leira (Eds.), Gender, welfare state and the market. New York: Routledge.

Social Exclusion Unit. (1999). Teenage pregnancy. London: Stationery Office.

Statistics Sweden. (1994). The Swedish survey of living conditions. Appendix 16. Internet. http://www.scb.se/statistik/LE/LE0101/_dokument/Appendix_16.PDF. Accessed 12.06.09.

Statistics Sweden. (2005). Children and their families 2004. Stockholm: Statistics Sweden. (Demographic Reports 2005:2).

Statistics Sweden. (2006). The Swedish survey of living conditions. Supplement to Appendix 16. Internet. http://www.scb.se/statistik/LE/LE0101/Supplement16. pdf. Accessed 12.06.09.

Swann, C., Bowe, K., McCormick, C., \& Kosmin, M. (2003). Teenage pregnancy and parenthood: Review of reviews. London: NHS Health Development Agency.

Trifiletti, R., Pratesi, A., \& Simoni, S. (2001). Care arrangements in single paren families. National Report: Italy SOCCARE Project Report 2.3. European Commission.

Viitanen, T. K. (2005). Cost of childcare and female employment in the UK. Review of Labour Economics E' Industrial Relations, 19(Special Issue), 149-170.

Whitehead, M., Burström, B., \& Diderichsen, F. (2000). Social policies and the pathways to inequalities in health: a comparative analysis of lone mothers in Britain and Sweden. Social Science \& Medicine, 50, 255-270.

Wisdom, J. P., Berlin, M., \& Lapidus, J. A. (2005). Relating health policy to women's health outcomes. Social Science E Medicine, 61(8), 1776-1784. 